\title{
Development of an efficient and practical approach for the synthesis of Montelukast Sodium Intermediate
}

\author{
Javad Mokhtari Aliabad*, Negin Hosseini, Khashayar Karimian, Morteza Rouhani \\ Department of Chemistry, Science and Research Branch, Islamic Azad University, Teharn, Iran \\ Email: j.mokhtari@srbiau.ac.ir
}

\begin{abstract}
:
A modified and scalable procedure for the generation of montelukast (Singulair, drug for asthma) based on a novel and useful way of performing the key substitution reaction has been presented. The present approach is recognized from the prior solutions in the application of inexpensive and accessible materials, which ensures very simple and economic production method. Our suggested approach for the production of montelukast is capable to minimize an amount of impurities and lets the efficient production of montelukast and its scale-up.
\end{abstract}

Keywords: Montelukast sodium; Singulair; asthma; drug synthesis; chronic therapy.

\section{Introduction:}

Montelukast $\mathbf{1}$ is a famous drug demonstrated for the chronic and prophylaxis therapy of asthma. ${ }^{1-4}$ It behaves as a selective antagonist of the leukotriene $\mathrm{D}_{4}$ receptor which causes the decrease of broncho constriction and eventuates in less inflammation. Montelukast is prescribed orally once daily which gives a profit in contrast with other drugs for pulmonary diseases such as 
asthma. $^{1-4}$ The sodium salt of montelukast characterized with formula $\mathbf{1}$, is utilized for asthma therapy (Figure 1).

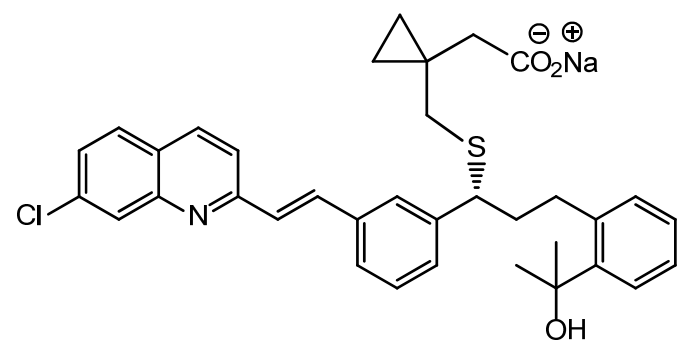

Figure 1: Montelukast sodium chemical structure.

The endeavors of Merck Frosst, causing to the finding and probable commercialization of Montelukast (at once $\$ 4.5$ billion-a-year drug before the expiration of its patent in 2012), has frequently been indicated as a "case study in novel drug development and discovery". 5 However, there stays domain both to modify available tactics and to extend new ones which address deficencies in known synthetic approaches to $\mathbf{1}$.

A synthetic way commonly indicative of operations utilized for $\mathbf{1}$ is shown in Scheme 1. This uses a Mizoroki-Heck reaction of methyl 2-iodobenzoate with allylic alcohol in a significant $\mathrm{C}-\mathrm{C}$ bond-forming step, pursued by asymmetric reduction of ketone 4. An important disadvantage of this way is the addition of the methyl Grignard reagent to the aryl ester 5 that causes to the dimethyl aryl carbinol 6. This needs the utilize of anhydrous cerium chloride and a great amount of reagent and entails a boring workup approach because of emulsion formation within the solvent extraction flow. ${ }^{6}$ 


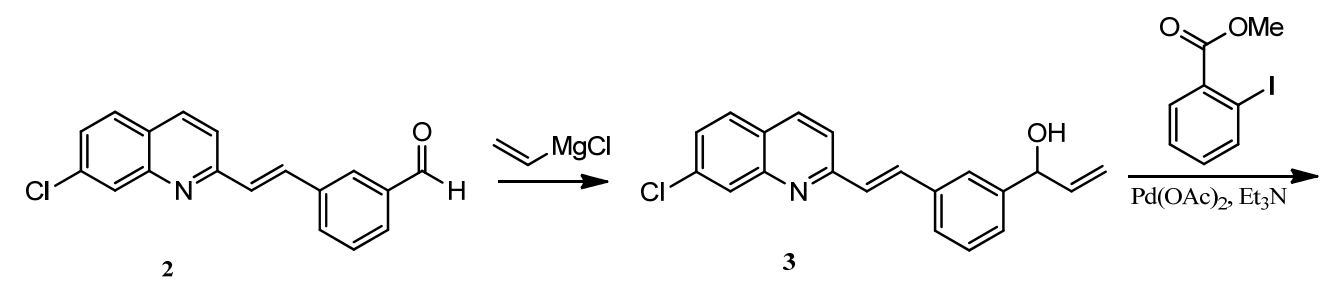<smiles>COC(=O)c1ccccc1CC[C@@H](O)c1cccc(/C=C/c2ccc3ccc(Cl)cc3n2)c1</smiles><smiles>CO[C@H](CCc1ccccc1C(C)(C)O)c1cccc(/C=C/c2ccc3ccc(Cl)cc3n2)c1</smiles><smiles>CCCC1(CC(=O)O)CC1</smiles>

Scheme 1: Routine synthesis approach of Montelukast sodium 1.

There are various functional groups in the Montelukast chemical structure that damage the chemical stability of this molecule (see Figure 1). Montelukast $\mathbf{1}$ is identified to be prone to multiple kinds of degradation. ${ }^{7-14}$ It is usually the instance of the following chemical transformation: dehydration at the tert-alcohol group, producing the corresponding olefin ${ }^{13}$, dehalogenation reaction ${ }^{14}$, photoisomerisation at the site of the double bond from geometry $(E)$ to $(Z)^{11,12}$, oxidation of the mercapto group to the sulfoxide..$^{8-11}$ The chemical impurities are mainly taken away by using crystallization in the phase of Montelukast acid. ${ }^{15}$ or in the phase of Montelukast salts with amines. ${ }^{13,16,17}$

The low stability and complex synthesis of Montelukast $\mathbf{1}$ present multitude difficulties for its large-scale production. Our present study demonstrates a novel and the industrially scalable 
process for the preparation of sodium (S,E)-2-(1-(((1-(3-(2-(7-chloroquinolin-2-yl)vinyl)phenyl)3-(2-(methoxycarbonyl)phenyl)propyl)thio)methyl)cyclopropyl)acetate which is one of the key intermediates of the Montelukast sodium synthesis process. We demonstrated a novel process that resolves multitude prior limitations and problems.

Our modified process (see in scheme 2), which details are shown in this paper, is appropriate for large-scale production of the active pharmaceutical ingredient (API) with many benefits generally known as Montelukast. 

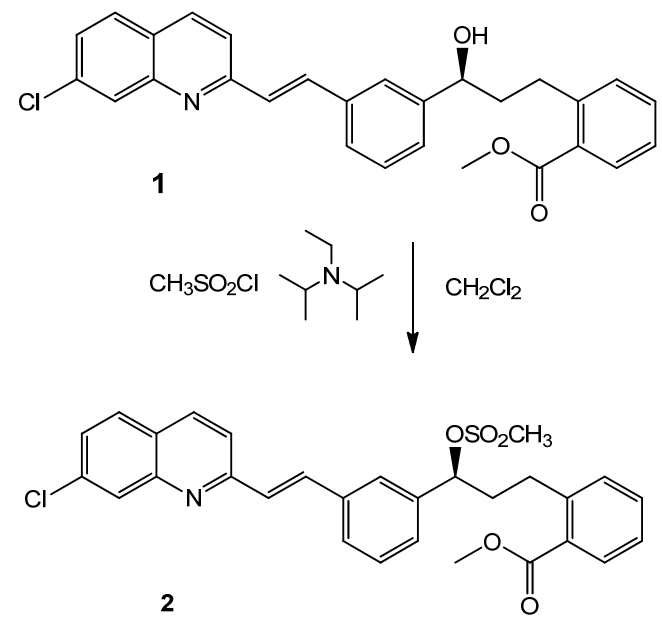

$\underbrace{\mathrm{SH}}_{-\mathrm{CO}_{2} \mathrm{H}} \downarrow \mathrm{PhCH}_{3}, 70^{\circ} \mathrm{C}$<smiles>COC(=O)c1ccccc1CC[C@H](SCC1(CC(=O)O)CC1)c1cccc(/C=C/c2ccc3ccc(Cl)cc3n2)c1</smiles><smiles>COC(=O)CC1(CS[C@@H](CCc2ccccc2C(=O)OC)c2cccc(/C=C/c3cccc([C@@H](CCc4ccccc4C(=O)OC)SCC4(CC(=O)O[Na])CC4)c3)c2)CC1</smiles>

Scheme 2: Synthetic pathway of Montelukast sodium derivative. 


\section{Experimental:}

The reagents and solvents used in this work were obtained from from Merck (Germany), SigmaAldrich and Fluka (Buchs, Switzerland) and used without further purification. IR spectra were recorded on a Shimadzu IR-460 spectrometer. Mass spectra were recorded on a FINNIGANMAT 8430 mass spectrometer operating at an ionization potential of $70 \mathrm{eV} .{ }^{1} \mathrm{H}$ and ${ }^{13} \mathrm{C}$ NMR spectra were recorded at 500.1 and $125.7 \mathrm{MHz}$, respectively, on a BRUKER DRX 500AVANCE FT-NMR instrument with $\mathrm{CDCl}_{3}$ as solvent.

Synthesis of dicyclohexylamine (R,E)-2-(1-(((1-(3-(2-(7-chloroquinolin-2-yl)vinyl)phenyl)-3(2-(methoxycarbonyl)phenyl)propyl)thio)methyl)cyclopropyl)acetate (5):

(S,E)-methyl 2-(3-(3-(2-(7-chloroquinolin-2-yl)vinyl)phenyl)-3-hydroxypropyl)benzoate 1 (0.5

g, $1 \mathrm{mmol}$ ) was taken in a dry $50 \mathrm{ml}$ round-bottom flask, equipped with a stir bar. Dichloromethane $(5 \mathrm{ml})$ was added into the reaction flask, and the mixture thus obtained was cooled at $5{ }^{\circ} \mathrm{C}$ in an ice bath and stirred for $15 \mathrm{~min}$ in order to dissolve all solids and obtain a clear solution. The diisopropylethylamine $(1.5 \mathrm{ml}, 8 \mathrm{mmol})$ was added dropwise into the cooled reaction mixture. Thereafter, methanesulfonyl chloride $(0.42 \mathrm{ml}, 5 \mathrm{mmol})$ which was dissolved in dicholormethane $(5 \mathrm{ml})$ was added to the reaction mixture dropwise. After stirring for 20 minutes at $5{ }^{\circ} \mathrm{C}$, the temperature of the reaction mixture was increased to room temperature and stirring was continued for more 3 hours. After nearly complete conversion into the corresponding $(S, E)$ methyl 2-(3-(3-(2-(7-chloroquinolin-2-yl)vinyl)phenyl)-3-((methylsulfonyl)oxy)propyl)benzoate 2, as was indicated by TLC monitoring, the $\mathrm{HCl} 10 \%$ aqueous solution (10 $\mathrm{ml})$ and $\mathrm{CH}_{2} \mathrm{Cl}_{2}(5$ $\mathrm{ml}$ ) were added to the mixture and stirring was continued for further $20 \mathrm{~min}$ at room temperature. Hence, the product was transformed into the organic phase. After separation of the organic 
phase, it was dried with anhydrous sodium sulfate. Then, the solvent evaporated by rotary evaporator and hence product 2 was obtained as a brown oil.

In the next step, the product 2, 2-(1-(mercaptomethyl)cyclopropyl)acetic acid $(0.137 \mathrm{~g}, 1 \mathrm{mmol})$ and toluene $(1 \mathrm{ml})$ were taken in a round-bottom flask and the mixture was stirred at $70{ }^{\circ} \mathrm{C}$ for 1 hour. After completion the reaction (monitored by TLC), the product was crystallized by the proper amount of dicyclohexylamine in acetone to formed compound $\mathbf{4}$ and then was stirred in the presence of sodium methoxide at room temperature for 1 hour to produce the derivative of the Montelukast sodium salt 5 with total yield $88 \%$.

Spectral data of the product 4. Off-white solid, IR $(\mathrm{KBr})\left(v_{\max }, \mathrm{cm}^{-1}\right): 3431,3039,2930,2859$, 2668, 2530, 2300, 3039, 1724,1532, 1457, $693 \mathrm{~cm}^{-1},{ }^{1} \mathrm{H} \mathrm{NMR}\left(500 \mathrm{MHz}, \mathrm{CDCl}_{3}\right) \delta:$ 0.25-0.45 (m, $2 \mathrm{CH}_{2}$ of cyclopropyl ring); $1.08-1.95$ (2m, $5 \mathrm{CH}_{2}$ of cyclohexyl rings); 2.26 (m, $\mathrm{CH}_{2}$ adjacent to C-S); 2.55 (m, $\mathrm{CH}_{2}$ adjacent to $\mathrm{CO}_{2}^{-}$); 2.90 (m, $\mathrm{CH}_{2}$ adjacent to $\mathrm{S}$ ); 2.85 (m, $\mathrm{CH}$ of cyclohexyl rings); $2.55\left(\mathrm{~m}, \mathrm{~S}-\mathrm{CH}-\mathrm{CH}_{2} \mathrm{CH}_{2}\right) ; 3.78\left(\mathrm{~s}, \mathrm{COOCH}_{3}\right) ; 4.45(\mathrm{t}, 1 \mathrm{H}, \mathrm{CH}-\mathrm{S}) ; 7.94(\mathrm{~m}, 15 \mathrm{H}$ of aromatic and vinylic $\mathrm{CH}) ; 8.4\left(\mathrm{~m}, \mathrm{NH}_{2}{ }^{+}\right) .{ }^{13} \mathrm{C} \mathrm{NMR}\left(125 \mathrm{MHz}, \mathrm{CDCl}_{3}\right) \delta: 11.94$ and $12.51\left(2 \mathrm{CH}_{2}\right.$ of cyclopropyl ring); 17.2 (C of cyclopropyl ring); 29.50 and $24.53\left(\mathrm{CH}_{2}\right.$ of dicyclohexyl); 52.69 $\left(\mathrm{CH}_{2}\right.$ attached to cyclopropyl ring); $63.04(\mathrm{C}-\mathrm{S}) ; 63.14\left(\mathrm{CH}\right.$ of cyclohexyl); $52.69\left(\mathrm{OCH}_{3}\right) ;$ 122.35 and 160.32 (aromatic and vinylic $\mathrm{CH}) ; 167.60\left(\mathrm{COOCH}_{3}\right) ; 170.00\left(\mathrm{COO}^{-}\right) . \mathrm{MS}(\mathrm{EI}): \mathrm{m} / \mathrm{z}$ $(\%)=41(45 \%), 138(30 \%), 188(72 \%), 290(100 \%), 439(64 \%)$.

Spectral data of the product 5: Off-white solid; IR (KBr) $\left(v_{\max }, \mathrm{cm}^{-1}\right): 3432,2928,2850,2664$, , 1722,1530, 1453, ${ }^{1} \mathrm{H}$ NMR (500 MHz, $\mathrm{CDCl}_{3}$ ) $\delta: 0.25-0.46$ (m, 2 $\mathrm{CH}_{2}$ of cyclopropyl ring), 2.24 (m, $\mathrm{CH}_{2}$ adjacent to C-S); 2.52 ( $\mathrm{m}, \mathrm{CH}_{2}$ adjacent to $\left.\mathrm{CO}_{2}{ }^{-}\right) ; 2.93$ (m, $\mathrm{CH}_{2}$ adjacent to $\mathrm{S}$ ); 2.56 (m, 
$\left.\mathrm{CH}_{2}\right) ; 3.79\left(\mathrm{~s}, \mathrm{COOCH}_{3}\right) ; 4.44(\mathrm{t}, 1 \mathrm{H}, \mathrm{CH}-\mathrm{S}) ; 7.94-8.41(\mathrm{~m}, 15 \mathrm{H}$ of aromatic and vinylic $\mathrm{CH})$. ${ }^{13} \mathrm{C}$ NMR (125 MHz, $\left.\mathrm{CDCl}_{3}\right) \delta: 11.93$ and $12.49\left(2 \mathrm{CH}_{2}\right.$ of cyclopropyl ring); 17.4 (C of cyclopropyl ring); $52.7\left(\mathrm{CH}_{2}\right.$ attached to cyclopropyl ring); 63.1 (C-S); $52.69\left(\mathrm{OCH}_{3}\right) ; 122.38$ 160.28 (aromatic and vinylic $\mathrm{CH}) ; 167.64\left(\mathrm{COOCH}_{3}\right) ; 170.04\left(\mathrm{COO}^{-}\right)$. $\mathrm{MS}(\mathrm{EI}): \mathrm{m} / \mathrm{z}(\%)=41$ (43\%), $138(60 \%), 188(54 \%), 290(100 \%), 439(78 \%)$.

\section{Results and discussions:}

To find out the best base and solvent for the first step, the model reaction was studied under various conditions and the results are listed in Table 1.<smiles>COC(=O)c1ccccc1CCC(O)c1cccc(/C=C/c2ccc3ccc(Cl)cc3n2)c1/C=C/c1cccc(C(O)CCc2ccc3ccc(Cl)cc3n2)c1</smiles>

Table 1: Reaction between (S,E)-methyl 2-(3-(3-(2-(7-chloroquinolin-2-yl)vinyl)phenyl)-3-hydroxypropyl)benzoate and methanesulfonyl chloride under different solvent and base conditions.

\begin{tabular}{cccc}
\hline Entry & Base & Solvent & Yield (\%) \\
\hline $\mathbf{1}$ & $\mathrm{Et}_{3} \mathrm{~N}$ & $\mathrm{CH}_{2} \mathrm{Cl}_{2}$ & 85 \\
$\mathbf{2}$ & $\mathrm{Et}{ }_{3} \mathrm{~N}$ & $\mathrm{THF}$ & 80 \\
$\mathbf{3}$ & Pyridine & $\mathrm{CH}_{2} \mathrm{Cl}_{2}$ & 90 \\
$\mathbf{4}$ & Pyridine & $\mathrm{THF}$ & 87 \\
$\mathbf{5}$ & Diisopropylethylamine & $\mathrm{CH}_{2} \mathrm{Cl}_{2}$ & 95 \\
$\mathbf{6}$ & Diisopropylethylamine & $\mathrm{THF}$ & 90 \\
\hline
\end{tabular}

As can be seen from Table 1, the best result was obtained by $\mathrm{Et}_{3} \mathrm{~N}$ and $\mathrm{CH}_{2} \mathrm{Cl}_{2}$ to yield product 2 in good yield (Table 1, Entry 1). Encouraged by this success, synthesis of the target compound 5 was done following the synthetic approach explained in scheme 2 . A primary reported synthetic pathway involves the reaction of 2-(2-(2- (3(R)-(3-(2-(7-chloro-2-quinolinyl)-ethenyl) phenyl)-3(methanesulfonyloxy) propyl)-phenyl)-2-propoxy) tetrahydro pyran $^{18}$ with methyl 1(acetylthiomethyl) cyclopropane acetate in the presence of caesium carbonate and hydrazine in 
acetonitrile as solvent to produce methyl ester of Montelukast in pyran-protected form. The protected compound is subsequent reacted with pyridinium, $p$-toluene sulfonate, to produce Montelukast. Hence, the pathway contains numerous steps with a sequence of protection and deprotection of the diol intermediate; expensive crude materials; usage of hazardous, and typical reaction situations at frigorofic conditions $\left(-25^{\circ} \mathrm{C}\right)$. Boring work-up approaches done for the purification of the essential product caused in extreme time cycles, giving the approach more expensive and less ecofriendly and hence, offering the pathway to be less inclined for industrial scaling.

Thus, to dominate these deficiencies, a novel alternate approach was extended for the production of Montelukast wherein (S,E)-methyl 2-(3-(3-(2-(7-chloroquinolin-2-yl)vinyl)phenyl)-3hydroxypropyl)benzoate 1 was exposed to mesylation with methane sulfonyl chloride, pursued by condensation with 2-(1-(mercaptomethyl)cyclopropyl)acetic acid to give $(R, E)-2-(1-(((1-(3-$ (2-(7-chloroquinolin-2-yl)vinyl)phenyl)-3

(2(methoxycarbonyl)phenyl)propyl)thio)methyl)cyclopropyl)acetic acid 3, which was isolated as its dicyclohexyl-amine salt $\mathbf{4}$ in pure form. Dicyclohexyl-amine salt function in $\mathbf{4}$ was converted into sodium salt by treating with sodium methoxide to produce Montelukast derivative 5 in $88 \%$ yield (Scheme 2). Hence, a novel industrially scalable pathway has been explained for the provision of Montelukast sodium.

\section{Conclusion:}

In summary, we have presented a novel and feasible process for the synthesis of montelukast sodium derivative in good yield via simply available initial materials. Hence, our proposed approach is industrial scalable and eco-friendly in comparison of previous methods. 


\section{References:}

1. Labelle M, Belley M, Gareau Y, Gauthier JY, Guay D, Gordon R, Grossman SG, Jones TR, Leblanc Y. 1995. Discovery of MK-0476, a potent and orally active leukotriene $\mathrm{D}_{4}$ receptor antagonist devoid of peroxisomal enxyme induction. Bioorg Med Chem Lett 5(3): 283-288.

2. Schoors DF, De Smet M, Reiss T, Margolskee D, Cheng H, Larson P, Amin R, Somers G. 1995. Single dose pharmacokinetics, safety and tolerability of MK-0476, a new leukotriene $\mathrm{D}_{4}$-receptor antagonist, in healthy volunteers. Br J Clin Pharmacol 40(3): 277-280.

3. Markham A, Faulds D. 1998. Montelukast. Drugs 56(2): 251-256.

4. Noonan MJ, Chervinsky P, Brandon M, Zhang J, Kundu S, Mcburney J, Reiss TF. 1998. Montelukast, a potent leukotriene receptor antagonist, causes dose-related improvements in chronic asthma. Montelukast Asthma Study Group. Eur Respir J 11(6): 1232-1239.

5. Harrington PJ. 2011. Pharmaceutical Process Chemistry for Synthesis: Rethinking the Routes to Scale-Up; John Wiley \& Sons: Hoboken, NJ, 164-216.

6. Suri S, Sarin GS, Mahendru M. 2006. PCT Patent Application WO/2006/021974.

7. Radhakrishna T, Narasaraju A, Ramakrishna M, Satyanarayana A. 2003. Simultaneous determination of montelukast and loratadine by HPLC and derivative spectrophotometric methods. J Pharm Biomed Anal. 31(2): 359-368.

8. Dufresne C, Gallant M, Gareau Y, Ruel R, Trimble L, Labelle M. 1996. Synthesis of Montelukast (MK-0476) Metabolic Oxidation Products J Org Chem. 61(24): 8518-8525.

9. Nelson ED, Harmon PA, Szymanik RC, Teresk MG, Li L, Seburg RA, Reed RA. 2006. J Pharm Sci 95(7):1527-1539. 
10. Balani SK, Xu X, Pratha V, Koss MA, Amin RD, Dufresne C, Miller RR, Arison BH, Doss GA, Chiba M. 1997. Metabolic profiles of montelukast sodium (Singulair), a potent cysteinyl leukotriene1 receptor antagonist, in human plasma and bile. Drug Metab Dispos 25(11): 1282-1287.

11. Al Omari MM, Zoubi RM, Hasan EI, Khader TZ, Badwan AA. 2007. Effect of light and heat on the stability of montelukast in solution and in its solid state. J Pharm Biomed Anal 45(3): 465-471.

12. Smith GA, Rawls CM, Kunka RL. 2004. An automated method for the determination of montelukast in human plasma using dual-column HPLC analysis and peak height summation of the parent compound and its photodegradation product. Pharm Res 21(9):1539-1544.

13. Sterimbaum G, Shapiro E, Chen, K. 2007. WO 2007005965 A1 (TEVA Pharm.)

14. Saravanan M, Kumari KS, Reddy PP, Naidu MN, Babu, JM, Srivastava AK, Kumar TL, Sekhar BVVNC, Satyanarayana B. 2008. Identification, synthesis, isolation and spectral characterization of potential impurities of montelukast sodium. J Pharm Biomed Anal 48(3): 708-715.

15. Suri S, Singh J. 2004. WO 2004108679 A1 (Morephen Lab).

16. Bhupathy M, McNamara JM, Sidler DR, Volante RP, Bergan JJ. 1995. EP 0737186 B1 (Merck \& Co).

17. Reguri BR, Bollikonda S, Chandra SBVV, Kasturi RK, Aavula SK. 2005. US 20050107612 A1 (Reddys Lab).

18. Labelle M, Prasit P, Belley M, Blouin M, Champion E, Charette L, De Luca JG, Dufresne C, Frenette R, Gauthier JY, Grimm E, Grossman SG, Guay D, Herold EG, Jones TR, Lau CK, Leblanc Y, Leger S, Lord A, McAuliffe M, McFarlane C, Masson P, Metters KM, Ouimet N, 
Patrick DH, Perrier H, Pickett CB, Piechuta H, Roy P, Williams H, Wang Z, Xiang YB, Zamboni RJ, Ford-Hutchinson AW, Young RN. 1992. Bioorg Med Chem Lett 2(9): 11411146. 